\title{
Postharvest Physicochemical Properties and Fungal Populations of Treated Cucumber with Sodium Tripolyphosphate/Titanium Dioxide Nanoparticles during Storage
}

\author{
Ebtihal Khojah ${ }^{1}$, Rokayya Sami ${ }^{1, *} \mathbb{C}$, Mahmoud Helal ${ }^{2}$, Abeer Elhakem ${ }^{3}$, Nada Benajiba ${ }^{4}$, \\ Mohammed Saeed Alkaltham ${ }^{5}$ id and Ahmad Mohammad Salamatullah ${ }^{5}$ (D) \\ 1 Department of Food Science and Nutrition, College of Sciences, Taif University, P.O. Box 11099, \\ Taif 21944, Saudi Arabia; eykhojah@tu.edu.sa \\ 2 Department of Mechanical Engineering, Faculty of Engineering, Taif University, P.O. Box 11099, \\ Taif 21944, Saudi Arabia; mo.helal@tu.edu.sa \\ 3 Department of Biology, College of Science and humanities in Al-Kharj, Prince Sattam Bin Abdulaziz \\ University, Al-Kharj 11942, Saudi Arabia; a.elhakem@psau.edu.sa \\ 4 Department of Basic Health Sciences, Deanship of Preparatory Year, Princess Nourah Bint Abdulrahman \\ University, P.O. Box 84428, Riyadh 11671, Saudi Arabia; nabenajiba@pnu.edu.sa \\ 5 Department of Food Science \& Nutrition, College of Food and Agricultural Sciences, King Saud University, \\ Riyadh 11451, Saudi Arabia; malkaltham@ksu.edu.sa (M.S.A.); asalamh@ksu.edu.sa (A.M.S.) \\ * Correspondence: rokayya.d@tu.edu.sa
}

Citation: Khojah, E.; Sami, R.; Helal, M.; Elhakem, A.; Benajiba, N.; Alkaltham, M.S.; Salamatullah, A.M. Postharvest Physicochemical Properties and Fungal Populations of Treated Cucumber with Sodium Tripolyphosphate/Titanium Dioxide Nanoparticles during Storage. Coatings 2021, 11, 613. https:// doi.org/10.3390/coatings11060613

Received: 11 May 2021

Accepted: 19 May 2021

Published: 21 May 2021

Publisher's Note: MDPI stays neutral with regard to jurisdictional claims in published maps and institutional affiliations.

Copyright: (c) 2021 by the authors Licensee MDPI, Basel, Switzerland This article is an open access article distributed under the terms and conditions of the Creative Commons Attribution (CC BY) license (https:// creativecommons.org/licenses/by/ $4.0 /)$
Abstract: Cucumbers have a limited shelf-life, from 10 to 14 days at commercial temperatures with relative humidity $(80 \%)$. The aim of the work was to evaluate the postharvest physicochemical properties and fungal populations of cucumber treated with sodium tripolyphosphate/titanium dioxide nanoparticles during storage at $10{ }^{\circ} \mathrm{C}$ to prolong the shelf-life to 21 days. Cucumber samples treated with chitosan/sodium tripolyphosphate/titanium dioxide nanoparticles (Cu-CHS-TDNST) and (Cu-CHS-TDN-ST) were found to be in a well-hydrated state and with a green-colored appearance upon day 21, with excellent quality for consumption. Chitosan coating (Cu-CHS) alone prolonged the cucumber shelf-life for 14 days of storage. The $\mathrm{Cu}-\mathrm{CHS}$ coating was less evident in reducing the respiration rate of cucumbers on day 14 than both nanocoatings, which were reported at the end of the storage period to be 5.09 and $5.38 \mathrm{mg} \cdot \mathrm{kg}^{-1} \mathrm{~h}^{-1}$ for $\mathrm{Cu}-\mathrm{CHS}-\mathrm{TDN}-\mathrm{ST}$ and $\mathrm{Cu}$ CHS-TDN, respectively. The Cu-CHS-TDN-ST treatment reduced the loss of ascorbic acid content to $13.17 \mathrm{mg} / 100 \mathrm{~g}$, delayed chilling injury, and had the highest chlorophyll contents during the whole storage period. The presence of sodium tripolyphosphate with the nanocoating delayed tissue damage. Peroxidase enzyme activity reached the maximum of $54.65 \mathrm{Ug}^{-1}$ for Cu-CHS-TDN-ST on day 21, followed by Cu-CHS-TDN $50.1 \mathrm{Ug}^{-1}$. On day 21, the fungal populations of Cu-CHS-TDN samples (3.77 $\log \mathrm{CFU} / \mathrm{g}$ ) were more than that of Cu-CHS-TDN-ST (3.15 log CFU/g) against CuControl (100\% spoiled). It was noted that the Cu-CHS-TDN-ST and CHS-TDN-ST coating treatments were capable of preserving the cucumber samples' quality during storage. The addition of sodium tripolyphosphate as a crosslinker for stabilizing the nanoparticle polymers in the coating treatments prolonged the shelf-life and achieved excellent quality for the cucumbers.

Keywords: cucumber; coating; sodium tripolyphosphate; chitosan; nanoparticles; shelf-life

\section{Introduction}

Cucumber (Cucumissativus L.) is a low-calorie fruit, rich in iron, magnesium, and potassium with a high moisture content. Cucumber quality is based on several factors such as shape, color, texture, size, absence of any signs of physical or microbial changes [1]. During the postharvest process, the cucumber tends to have some physicochemical changes, microbial populations, and desiccation, which influence the appearance and lower the nutrients. The moisture loss resulting from the transpiration process leads to wilting, 
shrinkage, softening, and accelerates senescence. The microbial population is commonly caused by bacteria such as (Xanthomonas and Erwinia spp.), and by fungi such as (Rhizopus and Alternaria spp.) [2]. A storage condition of $7{ }^{\circ} \mathrm{C}$ is unfavorable as they are chill sensitive [3]. A chilled condition of $10{ }^{\circ} \mathrm{C}$ was applied to solve those problems which became more disposed to the quality loss after 2 weeks [4]. Novel techniques are needed for developing a sufficient moisture barrier and the antimicrobial support to prolong the cucumbers' shelf-life by waxing which have several disadvantages [5]. Treating with semipermeable films is another technique used to delay the ripening processes [6-9]. Chitosan is effective against antifungal activities as it elicits the fungal cell wall degrading enzymes such as chitinase, phytoalexins $0-1$, and 3-glucanase [10,11]. Recently, nanotechnology materials have appeared in all areas of life, due to their extremely small size [12]. Titanium dioxide nanoparticles $\left(\mathrm{TiO}_{2}\right)$ are manufactured worldwide in high quantities, due to their many uses in cosmetics, plastics, and paint, and even in foods $[13,14]$. The American Food and Drug Administration (AFDA) reported that $\mathrm{TiO}_{2}$ nanoparticles are non-toxic and safe to be used in human food. They are used for their white coloring, photo-protective, coloring of $\mathrm{TiO}_{2}$ photoprotective, and photocatalytic properties. Furthermore, consideration for plant protection extends the shelf-life of the active ingredients [15,16]. Sodium tripolyphosphate is an economical chemical component that can act as a crosslinker for stabilizing the nanoparticle polymers in nanoparticle formations [17].

Therefore, the current study aims to determine some of the postharvest physicochemical properties and microbial population effect of cucumber treated with sodium tripolyphosphate/titanium dioxide nanoparticles during storage.

\section{Materials and Methods}

\subsection{Coating Materials}

The materials used for the coating solutions were sodium tripolyphosphate, titanium dioxide nanoparticles (particle size: $30 \mathrm{~nm}$ ), chitosan (deacetylation medium of $85 \%$ molecular weight), and acetic acid (98\%) as a preservative. All the used materials in the current study were obtained from (Benchmark, St. Louis, MO, USA).

\subsection{Plant Materials and Coating Processes}

Aark green, cucumber (Cucumissativus L.) cultivar was obtained from a private orchard at Taif City, Saudi Arabia. The harvested cucumber fruits were selected for the color, maturity and lack of any physiological and pathological disorders. Fruits were divided into four sets in three replicate and each one included 20 uniform cucumber samples. Control cucumber set (Cu-Control) was immersed for $10 \mathrm{~s}$ in distilled water instead of coating solutions then air-dried before storage. Chitosan (1\%) solution was prepared with $0.1 \mathrm{M}$ citric acid and sonicating overnight. The second set of cucumbers (Cu-CHS) were dipped in a coating solution of chitosan for $10 \mathrm{~s}$, while the third set (Cu-CHS-TDN) was coated with chitosan/titanium dioxide nanoparticles $1 \%$. The fourth coating set was (Cu-CHS-TDNST) with the addition of sodium tripolyphosphate $2 \%$ as a crosslinker for stabilizing the nanoparticles. The main factor was the chilled condition periods at $10{ }^{\circ} \mathrm{C}$ and the quality parameters were recorded at $0,7,14$, and 21 days of the storage period.

\subsection{Chilling Injury}

Chilling injury degree is a physiological disorder that results in surface pitting, decay and intercellular movement $[7,18]$. The chilling injury was determined every seven days after cucumbers were transferred from the refrigerator to the ambient temperature. Chilling injury degree ranged (from 0 to 1 ) according to the Equation (1) [19]:

$$
\text { Chilling injury }(\mathrm{CI})=\frac{\sum[(\text { CIscale }) \times(\text { number of cucumbers at } \mathrm{CI})]}{4 \times \text { total number of cucumbers per treatment }}
$$

where $0=$ no signs of pitting, 1, 2, 3, and 4 represent $<25 \%, 25 \%$ to $50 \%, 51 \%$ to $75 \%$, and $>75 \%$, respectively. 


\section{4. $\mathrm{CO}_{2}$ Respiration Rate}

The respiration rate for the treated cucumbers was evaluated during storage by placing in an airtight chest, a $\mathrm{CO}_{2}$ sensor (Testo AG-435-2, Co. KGaA, Testo, Germany) to monitor the concentration at 1-min intervals for $60 \mathrm{~min}$, and expressed as $\mathrm{mg} \cdot \mathrm{kg}^{-1} \mathrm{~h}^{-1}$ according to the Equation (2) [11,20].

$$
\text { Respiration rate }\left(\mathrm{mg} \cdot \mathrm{kg}^{-1} \mathrm{~h}^{-1}\right)=\frac{\left(\Delta y_{\mathrm{CO} 2} \times V\right)}{(100 \times W \times \Delta t)}
$$

where $\Delta y_{\mathrm{CO} 2}=$ concentration $(\%), V(\mathrm{~mL})=$ free volume, $W(\mathrm{~kg})=$ weight, and $\Delta t(\mathrm{~s})=$ testing time in seconds.

\subsection{Chlorophyll Contents}

The chlorophyll contents were evaluated by mixing $5 \mathrm{~g}$ of various samples with $20 \mathrm{~mL}$ of $80 \%$ acetone for $30 \mathrm{~s}$. The mixtures were centrifuged, measured at $654,663 \mathrm{~nm}$, and expressed in $\mathrm{mg} / \mathrm{g}$ according to the Equations (3) and (4) [21].

$$
\begin{aligned}
& \text { ChlorophyIIa }=\left[12.7\left(A_{663}\right)-2.69\left(A_{645}\right)\right] \times \frac{V}{1000 \times W \times a}(\mathrm{mg} / \mathrm{g}) \\
& \text { ChlorophyIIb }=\left[22.9\left(A_{645}\right)-4.68\left(A_{663}\right)\right] \times \frac{V}{1000 \times W \times a}(\mathrm{mg} / \mathrm{g})
\end{aligned}
$$

where $A=$ absorbance, $W=$ weight in $(\mathrm{g})$, and $a=$ path length of light $(1 \mathrm{~cm})$

\subsection{Ascorbic Acid Content}

The amount of ascorbic acid content was detected by the titrimetric method using 2,6 Dichloro- phenol- indophenol dye as described in the following Equation (5) [11,22]:

$$
\text { Ascorbic acid content }(\%)=\frac{\text { titration volume } \times 111 \times \text { dilution factor } \times 100}{\text { sample volume } \times 1000}
$$

\subsection{Total Phenolic Content}

Determination of total phenolic contents reacting with phosphomolybdic acid by Folin-Ciocalteau reagent in alkaline medium, produced blue colored complex after incubation at $45{ }^{\circ} \mathrm{C}$ and detected at $765 \mathrm{~nm}[10,23]$. A standard curve was plotted by Gallic acid and the concentrations were expressed as $\mathrm{mg} / 100 \mathrm{~g}$.

\subsection{Antioxidant Activity}

The antioxidant activity was evaluated by DPPH (2,2-diphenyl-2-picrylhydrazyl) and FRAP (Ferric reducing antioxidant power) scavenging activity methods according to the following Equation (6) [24,25]:

$$
\text { Antioxidant activity }(\%)=\frac{A_{b r}-A_{a r}}{A_{b r}} \times 10
$$

where $A_{b r}=$ absorbance before reaction and $A_{a r}=$ absorbance after the reaction. Antioxidant activity values can be achieved by comparing the absorption changes.

\subsection{Peroxidase Enzyme Activity}

Peroxidase enzyme activity (POD) was evaluated with minor modifications [6,26]. Approximately $1 \mathrm{~g}$ of treated cucumbers homogenized in $0.1 \mathrm{~mol} / \mathrm{L}$ pyrocatechol solution $(3 \mathrm{~mL})$ in a chilled mortar and centrifuged $12,000 \times g$ for $10 \mathrm{~min}$. The supernatants were taken and evaluated at $470 \mathrm{~nm}$ [26]. 


\subsection{Fungal Populations}

The measurements of fungal populations (yeast and mold counts) were carried out during the storage period every seven days until 21 days. A potato dextrose agar (PDA; Becton Dickinson, Franklin Lakes, NJ, USA) was applied as the medium for treated cucumbers. Approximately $10 \mathrm{~g}$ was used aseptically to prepare 1:10 dilutions, then added to a stomacher bag with $90 \mathrm{~mL}$ of $0.1 \%$ peptone water. The incubation temperature was $\left(20-25^{\circ} \mathrm{C}\right)$ and the plates were inspected after $48 \mathrm{~h}[27,28]$.

\subsection{Statistical Analysis}

All extractions were applied in triplicate, and the data obtained were expressed based on fresh weight. The data were subjected to Duncan's multiple range tests followed by SPSS statistical software (17.00). Significant differences were accepted at $p \leq 0.05$.

\section{Results and Discussion}

\subsection{Chilling Injury}

Chilling injury is a severe problem that affects a number of vegetables and fruits during chilled conditions. Symptoms of chilling injury appear as severe shriveling, surface pitting, sunken spots, water-soaked areas, and decay which could be due to ethylene, amino cyclopropane carboxylic acid, and putrescine increase [18,29]. The results of chilling injury of the treated cucumbers stored at $10{ }^{\circ} \mathrm{C}$ for 21 days are presented in Figure 1. On the 7th day, the chilling injury of 0.58 was severe in $\mathrm{Cu}$-Control and slight to moderate was reported in $\mathrm{Cu}-\mathrm{CHS}, 0.39$, while chilling injury was not detected in any nanocoated samples. A chilling injury index higher than 0.4 was considered unacceptable for customers. At the end of the 14th day of storage, $\mathrm{Cu}$-Control was spoiled, while $\mathrm{Cu}-\mathrm{CHS}$ was suffering severe chilling injury. On day 21, the $\mathrm{Cu}-\mathrm{CHS}$ samples were not in marketable condition, the $\mathrm{Cu}-\mathrm{CHS}-\mathrm{TDN}-\mathrm{ST}$ samples were in a more acceptable condition than the $\mathrm{Cu}-\mathrm{CHS}-$ TDN cucumbers. Therefore, the onset of chilling injury symptoms in the CHS-TDN-ST samples was the most delayed. Mohamed et al. [30] reported that coating materials could reduce catalase activity and improve flavonoid, phenolic, and alternative oxidase that involved modulating enzymes and could enhance visual quality and chemical composition during storage.

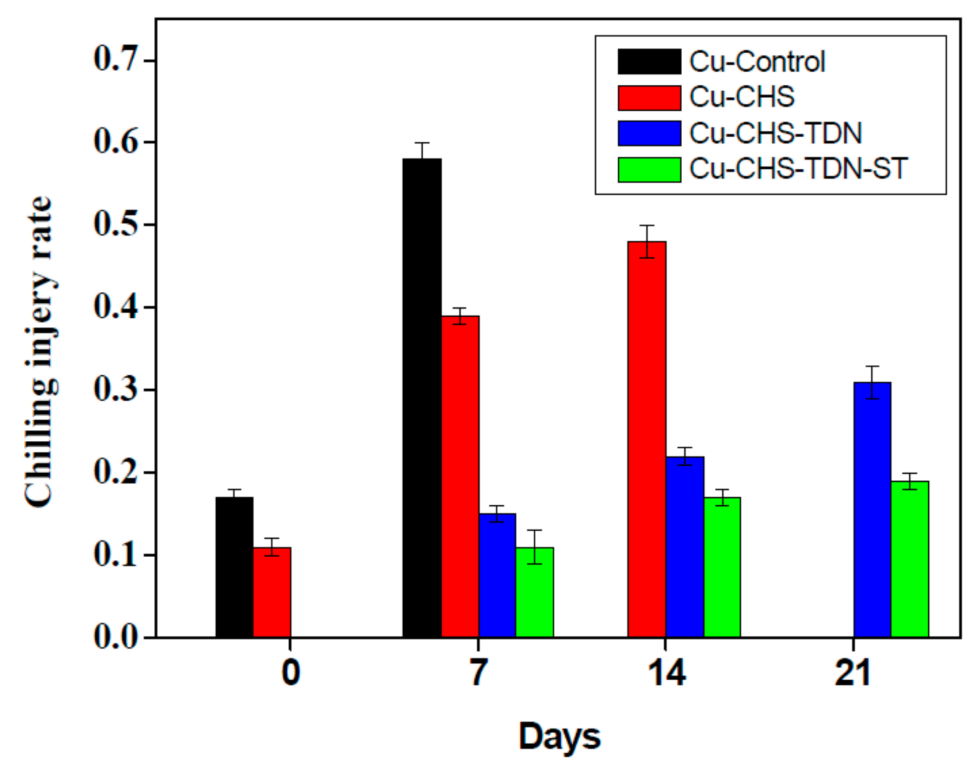

Figure 1. Effect of coating treatments on chilling injury. 


\subsection{Respiration Rate}

Respiration rate is one of the main factors which affects postharvest losses of cucumbers due to $\mathrm{O}_{2}$ consumption and $\mathrm{CO}_{2}$ subsequent production $[11,20]$. The respiration rate during storage is plotted in Figure 2. Results showed a high production of $\mathrm{CO}_{2}$ in the initial storage period for the untreated cucumbers. There was a minor decrease in respiration rate in the $\mathrm{Cu}-\mathrm{CHS}-\mathrm{TDN}$ and $\mathrm{Cu}-\mathrm{CHS}-\mathrm{TDN}-\mathrm{ST}$ coated cucumbers in comparison with $\mathrm{Cu}$ Control which reported $8.38 \mathrm{mg} \cdot \mathrm{kg}^{-1} \mathrm{~h}^{-1}$ on day 7 . The Cu-CHS coating was less evident in reducing the respiration rate of cucumbers on day 14 than both nanocoatings which were reported at the end of the storage period 5.09 and $5.38 \mathrm{mg} \cdot \mathrm{kg}^{-1} \mathrm{~h}^{-1}$ for Cu-CHSTDN-ST and Cu-CHS-TDN, respectively. Sodium tripolyphosphate can act as a crosslinker for stabilizing the nanoparticle polymers in nanoparticle formations and delay oxidation processes [11,17]. Ghidelli et al. [31] reported a lower respiration rate by chitosan coating, due to the gaseous barrier properties. The results of the current research suggest that the addition of sodium tripolyphosphate to nanocoating could have affected the metabolic reactions and delayed the senescence course of cucumbers during the storage period.

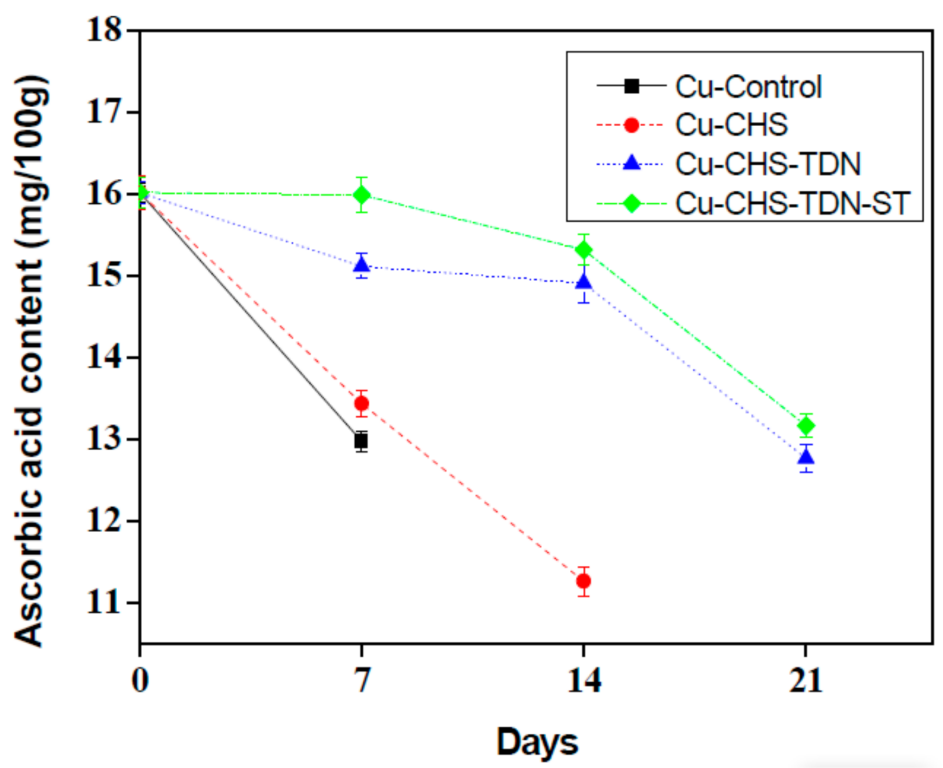

Figure 2. Effect of coating treatments on respiration rate.

\subsection{Chlorophyll Contents}

Chlorophyll is responsible for the green pigment of the cucumber peel, when chlorophyll is decomposed, the yellowness reduces the sensory evaluation and the marketing value [32,33]. Table 1 shows the changes in chlorophyll contents of cucumbers during 21 days of storage at $10{ }^{\circ} \mathrm{C}$. The chlorophyll degradation was initiated directly during storage which was at slower rates in coated cucumbers as compared with $\mathrm{Cu}$-Control. The chlorophyll "a" loss was $0.20 \mathrm{mg} / \mathrm{g}$ in Cu-CHS on day 14, while the nanocoated cucumbers $\mathrm{Cu}-\mathrm{CHS}-\mathrm{TDN}$ and $\mathrm{Cu}-\mathrm{CHS}-\mathrm{TDN}-\mathrm{ST}$ were similar at the end of the storage time, with 0.24 and $0.25 \mathrm{mg} / \mathrm{g}$, respectively, while $\mathrm{Cu}$-Control samples reached $0.17 \mathrm{mg} / \mathrm{g}$ loss on day 7 then were completely spoiled by the end of the storage period. The changes in chlorophyll " $b$ " contents were comparable to chlorophyll "a" contents with lower values under the same conditions. Hosam and Aly [34] observed a similar trend in lower chlorophyll contents after treating cucumber samples with chitosan, cassava starch, and gelatin. Throughout storage, the $\mathrm{Cu}-\mathrm{CHS}-\mathrm{TDN}-\mathrm{ST}$ samples had the highest chlorophyll content of all the treatments, which could be due to the combination of sodium tripolyphosphate and the nanocoating to reduce the conversion of chlorophyll to yellow-olive-colored pheophytin. 
Table 1. Effect of coating treatments on clorophyll contents.

\begin{tabular}{|c|c|c|c|c|}
\hline Days & Cu-Control & $\mathrm{Cu}-\mathrm{CHS}$ & Cu-CHS-TDN & Cu-CHS-TDN-ST \\
\hline \multicolumn{5}{|c|}{ Clorophyll $a(\mathrm{mg} / \mathrm{g})$} \\
\hline 0 & $0.23 \pm 0.01^{\mathrm{c}}$ & $0.24 \pm 0.03^{c}$ & $0.32 \pm 0.02^{b}$ & $0.34 \pm 0.01^{\mathrm{a}}$ \\
\hline 7 & $0.17 \pm 0.02^{\mathrm{d}}$ & $0.22 \pm 0.02^{\mathrm{c}}$ & $0.26 \pm 0.03^{b}$ & $0.28 \pm 0.03^{\mathrm{a}}$ \\
\hline 14 & - & $0.20 \pm 0.01^{b}$ & $0.27 \pm 0.02^{\mathrm{a}}$ & $0.27 \pm 0.02^{\mathrm{a}}$ \\
\hline 21 & - & - & $0.24 \pm 0.01^{\mathrm{a}}$ & $0.25 \pm 0.03^{a}$ \\
\hline \multicolumn{5}{|c|}{ Clorophyll $b$ (mg/g) } \\
\hline 0 & $0.10 \pm 0.03^{d}$ & $0.12 \pm 0.01^{c}$ & $0.16 \pm 0.02^{b}$ & $0.21 \pm 0.01^{\mathrm{a}}$ \\
\hline 7 & $0.09 \pm 0.02 \mathrm{~d}$ & $0.11 \pm 0.02^{c}$ & $0.14 \pm 0.03^{b}$ & $0.17 \pm 0.02^{\mathrm{a}}$ \\
\hline 14 & - & $0.08 \pm 0.03^{c}$ & $0.12 \pm 0.01^{b}$ & $0.14 \pm 0.02^{\mathrm{a}}$ \\
\hline 21 & - & - & $0.11 \pm 0.02^{b}$ & $0.13 \pm 0.03^{\mathrm{a}}$ \\
\hline
\end{tabular}

Each value presents as mean \pm standard deviation. Different letters indicate a significant difference $(p \leq 0.05)$.

\subsection{Ascorbic Acid Content}

The maintenance of ascorbic acid content in cucumber samples under various coating treatments and storage period was extremely significant. The values ranged from 16.02 to $12.77 \mathrm{mg} / 100 \mathrm{~g}$ until the end of the storage period. The ascorbic acid content of cucumbers, $16.02 \mathrm{mg} / 100 \mathrm{~g}$ was detected on the day of preparation. The ascorbic acid content was lower in $\mathrm{Cu}$-Control as $12.98 \mathrm{mg} / 100 \mathrm{~g}$ on day 7 . At the end of the 14th day, the $\mathrm{Cu}-\mathrm{CHS}$ samples reached a reduced $11.27 \mathrm{mg} / 100 \mathrm{~g}$, Figure 3. The $\mathrm{Cu}-\mathrm{CHS}-\mathrm{TDN}-\mathrm{ST}$ treatment reduced the loss of ascorbic acid content during the whole storage period. Vitamin C concentrations are highly sensitive to light, thus coating can enhance the ascorbic acid content during the storage period $[35,36]$. Similar effects were reported after coating treatments for several fruits and vegetables $[4,7]$. It was noted that the $\mathrm{Cu}-\mathrm{CHS}-\mathrm{TDN}-\mathrm{ST}$ coating treatment was capable of preserving the ascorbic acid content in cucumber during storage.

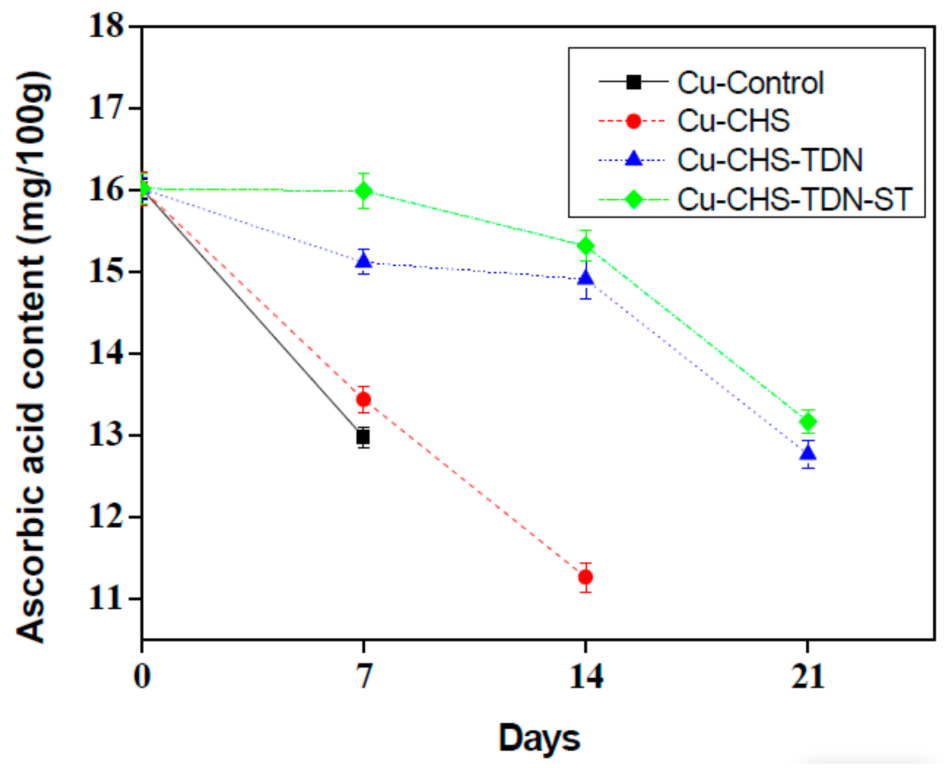

Figure 3. Effect of coating treatments on the ascorbic acid content.

\subsection{Total Phenolic Content}

Polyphenols are responsible for sensory evaluation and have an essential role in vivo and in vitro oxidation $[11,37]$. The total phenolic content in the cucumbers on the day of preparation was 232, 322, 343, and $375 \mathrm{mg} / 100 \mathrm{~g}$, respectively, Figure 4 . The coating treatments preserved the total phenolic contents compared to $\mathrm{Cu}$-Control which was spoiled at the end of the 7th day. The $\mathrm{Cu}-\mathrm{CHS}$ samples reached $167 \mathrm{mg} / 100 \mathrm{~g}$ at the end of the 14th day, while the nanocoated cucumbers retained a high total phenolic content until 
the end of the storage period. The Cu-CHS-TDN-ST and Cu-CHS-TDN treatments reported 213 and $192 \mathrm{mg} / 100 \mathrm{~g}$, respectively. Vallverdu-Queralt et al. [38] reported a decrease in the total phenolic contents of tomato during storage. Camargo and Dunoyer [39] suggested that chilling may help in increasing the total phenolic contents by changing the metabolism of the phenolic components.

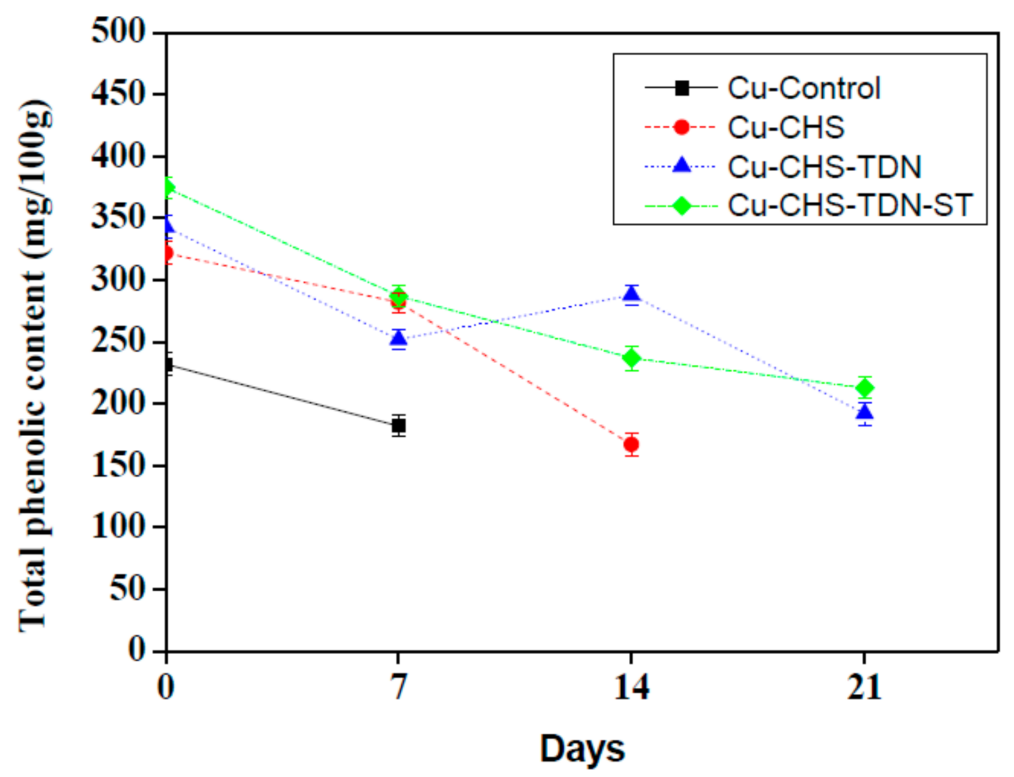

Figure 4. Effect of coating treatments on total phenolic content.

\subsection{Antioxidant Activity}

The effect of various coating treatments on antioxidant activities such as DPPH and FRAP are presented in Figure 5. The initial DPPH scavenging activity value in cucumbers was $55.14 \%$. The $\mathrm{Cu}$-Control samples reported $39.55 \%$ on the 7 th day, while $\mathrm{Cu}-\mathrm{CHS}$ reported $29.02 \%$ on the 14th day, Figure 5a. At the end of the storage period, the Cu-CHSTDN reported a high DPPH scavenging activity value of $27.73 \%$, while the $\mathrm{Cu}$-Control and $\mathrm{Cu}-\mathrm{CHS}$ samples were spoiled. The $\mathrm{Cu}-\mathrm{CHS}-\mathrm{TDN}-\mathrm{ST}$ samples reported the highest DPPH scavenging activity value at the end of the storage period compared to the other samples. It was noted that the chilled conditions, combinations of sodium tripolyphosphate, nanocoating, and chitosan coatings could decrease the antioxidant compound losses and enhance the postharvest quality of cucumbers. The decrease in antioxidant activity could be related to a decrease in the total phenolic, ascorbic acid contents, and redox status [40-43].

Figure $5 \mathrm{~b}$ shows the FRAP scavenging activity of cucumbers subjected to coating treatments and the storage period. The initial FRAP scavenging activity value of cucumbers was $0.79 \%$. A decrease in the FRAP scavenging activity was noticed in all treatments during the whole storage, ranging from $0.39 \%$ to $1.12 \%$. Cu-CHS samples reported $0.39 \%$ on day 14 then spoiled upon continuous storage. $\mathrm{Cu}$-CHS-TDN-ST $1.12 \%$ achieved the highest increase in FRAP scavenging activity value on day 21 followed by Cu-CHS-TDN $0.99 \%$. The presence of sodium tripolyphosphate and nano-coating enhanced the FRAP scavenging activity and delayed the tissue damage [20,44]. Results were linked with Zhang et al. [45] who reported higher antioxidant activities after coating cucumbers with chitosan-gsalicylic acid, while the reduction of the antioxidant activity of the uncoated cucumbers could be due to the decay and senescence. 


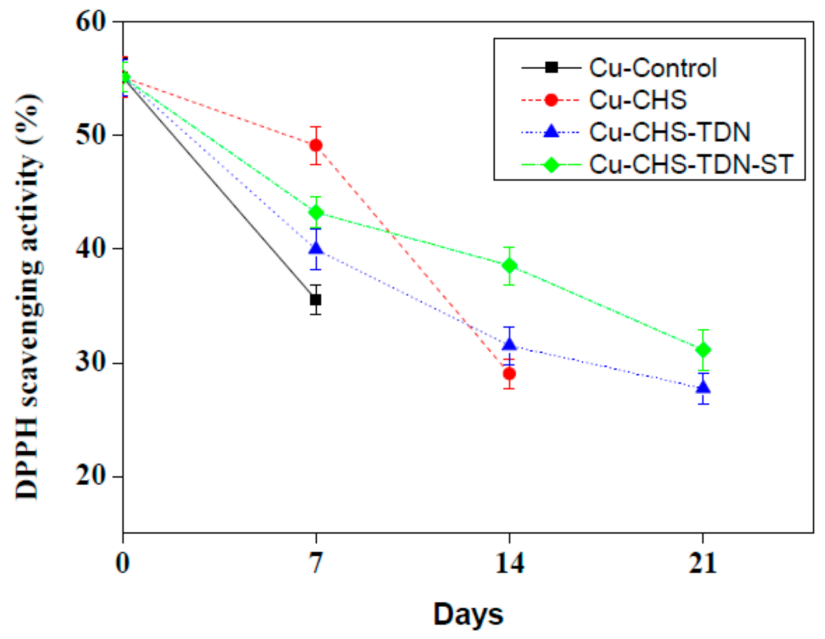

(a)

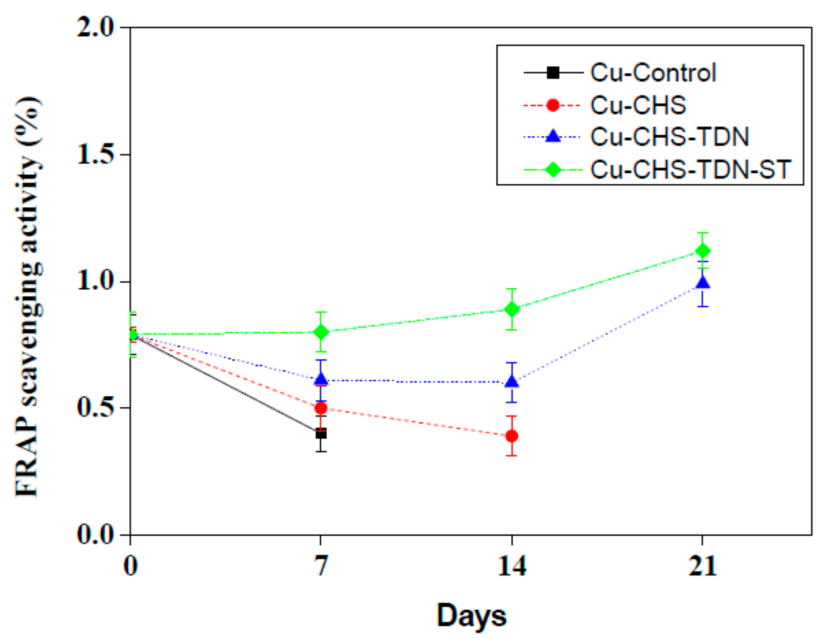

(b)

Figure 5. Effect of coating treatments on antioxidant activities; (a) DPPH and (b) FRAP scavenging activities.

\subsection{Peroxidase Enzyme Activity}

The cell walls of the plants are protected with antioxidant defense systems, such as enzymes, to support the cell walls $[9,46]$. Figure 6 shows that POD enzyme activities increased radically in all the cucumber samples during the whole storage period and reached the maximum $54.65 \mathrm{Ug}^{-1}$ for $\mathrm{Cu}-\mathrm{CHS}-\mathrm{TDN}-\mathrm{ST}$ on day 21 followed by $\mathrm{Cu}-\mathrm{CHS}$ $\mathrm{TDN}$, at $50.1 \mathrm{Ug}^{-1}$. The $\mathrm{Cu}-\mathrm{CHS}$ samples reached $43.18 \mathrm{Ug}^{-1}$ on the 14th day then spoiled upon continuous storage, compared with $\mathrm{Cu}$-Control which reached $28.34 \mathrm{Ug}^{-1}$, the lowest POD value on the 7th day, then completely spoiled upon continuous storage. Koh et al. [47] suggested that the maintenance of POD activity was related to the presence of consistent abiotic stress.

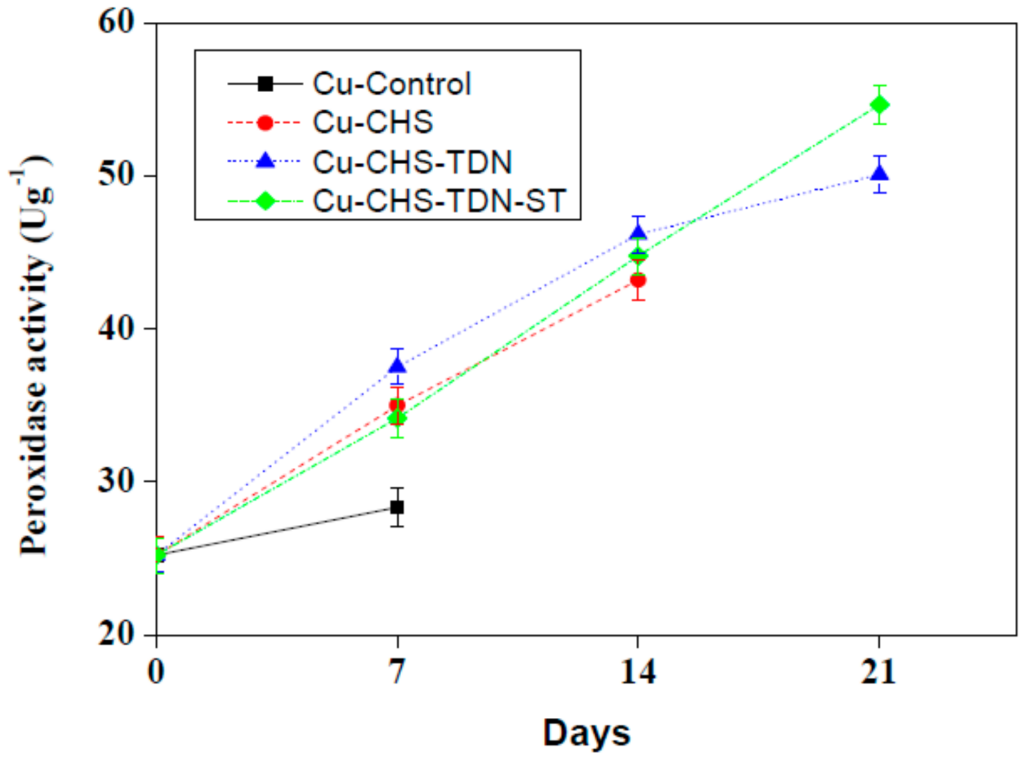

Figure 6. Effect of coating treatments on peroxidase enzyme activity.

\subsection{Fungal Populations}

Microbial safety is vital in evaluating the quality of the cucumbers. In this current research work, the effects of coating on fungal populations were examined in control and coated cucumbers. Table 2 presents the development of fungal populations of treated cucumber samples during the 21 days of storage at $10^{\circ} \mathrm{C}$, expressed as $\log \mathrm{CFU} / \mathrm{g}$. The 
fungal populations increased progressively upon a continuous storage period in both control and coated cucumbers. The rate of fungal populations was the highest in the $\mathrm{Cu}$-Control on the 7th day of storage and achieved a final fungal count of $3.91 \mathrm{log} \mathrm{CFU} / \mathrm{g}$, then it became completely spoiled before the 14th day as it was being largely contaminated by molds and yeasts. The $\mathrm{Cu}$-CHS treatment efficiently reduced the fungal populations for the first 14 days of storage, reported a little sign of fungal decay, $3.85 \log$ CFU/g, then it became completely spoiled before day 21 . On the other hand, no sign of any visual populations was detected for either of the nanocoated cucumbers. The results were linked with Waewthongrak et al. [48] who used chitosan for inhibiting the growth of pathogenic fungi in citrus fruits. On day 21, the fungal populations of the Cu-CHS-TDN samples (3.77 $\log \mathrm{CFU} / \mathrm{g}$ ) were more than that of Cu-CHS-TDN-ST (3.15 log CFU/g) against $\mathrm{Cu}-$ Control (100\% spoiled). It was noted that the Cu-CHS-TDN-ST and CHS-TDN-ST coating treatments were capable of preserving the cucumber sample's quality during storage. Though, $\mathrm{Cu}-\mathrm{CHS}-\mathrm{TDN}-\mathrm{ST}$ can be recommended as the most efficient antifungal treatment which kept cucumber samples in a well-hydrated state and with green-colored appearance upon day 21, with excellent quality for consumption. Sodium tripolyphosphate may act as a crosslinker for stabilizing the nanoparticle polymers in nanoparticle formations in coating treatments to prolong the shelf-life and achieve an excellent quality for cucumbers [17].

Table 2. Effect of coating treatments on fungal populations $(\log \mathrm{CFU} / \mathrm{g})$.

\begin{tabular}{ccccc}
\hline Days & Cu-Control & Cu-CHS & Cu-CHS-TDN & Cu-CHS-TDN-ST \\
\hline 0 & $2.08 \pm 0.21^{\mathrm{a}}$ & $2.08 \pm 0.13^{\mathrm{a}}$ & $2.08 \pm 0.12^{\mathrm{a}}$ & $2.08^{\mathrm{a}} \pm 0.15^{\mathrm{a}}$ \\
7 & $3.91 \pm 0.11^{\mathrm{a}}$ & $2.31 \pm 0.14^{\mathrm{c}}$ & $2.87 \pm 0.18^{\mathrm{b}}$ & $2.17 \pm 0.11^{\mathrm{d}}$ \\
14 & - & $3.85 \pm 0.11^{\mathrm{a}}$ & $3.15 \pm 0.14^{\mathrm{b}}$ & $2.98 \pm 0.13^{\mathrm{c}}$ \\
21 & - & - & $3.77 \pm 0.19^{\mathrm{a}}$ & $3.15 \pm 0.17^{\mathrm{b}}$ \\
\hline
\end{tabular}

Values in the same column with different superscripts $\mathrm{a}, \mathrm{b}, \mathrm{c}, \mathrm{d}$ are significantly different $p \leq 0.05$.

\section{Conclusions}

Cucumber fruits require a satisfactory preservation method in order to retain quality during storage. The coating treatments used were chitosan/sodium tripolyphosphate/titanium dioxide nanoparticles. The results reported that chitosan coating alone can preserve cucumber quality up to14 days in chilled conditions at $10^{\circ} \mathrm{C}$, while nanocoating treatments were capable of preserving the cucumber sample's quality during the whole storage period. POD enzyme activities reached the maximum of $54.65 \mathrm{Ug}^{-1}$ for Cu-CHSTDN-ST on day 21 followed by Cu-CHS-TDN $50.1 \mathrm{Ug}^{-1}$. On day 21, the fungal populations of the $\mathrm{Cu}$-CHS-TDN samples (3.77 log CFU/g) were more than that of Cu-CHS-TDN-ST (3.15 $\log \mathrm{CFU} / \mathrm{g}$ ) against Cu-Control (100\% spoiled).The addition of sodium tripolyphosphate as a crosslinker for stabilizing the nanoparticle polymers prolonged the cucumbers' shelf-life, achieved excellent postharvest quality and can be applied in the food industry.

Author Contributions: Methodology, writing-review and editing, E.K., M.H., R.S., A.E., and N.B.; visualization, M.S.A. and A.M.S. All authors have read and agreed to the published version of the manuscript.

Funding: This research received no external funding.

Institutional Review Board Statement: Not applicable.

Informed Consent Statement: Not applicable.

Data Availability Statement: Available upon request from the corresponding author.

Acknowledgments: Financial support was provided from the Deanship of Scientific Research by Taif University, award No. (102-441-1).

Conflicts of Interest: The authors declared no conflict of interest. 


\section{References}

1. Olawuyi, I.F.; Lee, W. Influence of chitosan coating and packaging materials on the quality characteristics of fresh-cut cucumber. Korean J. Food Preserv. 2019, 26, 371-380. [CrossRef]

2. Reddy, P.P. Bacterial Diseases and Their Management. In Sustainable Crop Protection under Protected Cultivation; Springer: Berlin/Heidelberg, Germany, 2016; pp. 153-159.

3. Wang, C.Y. Chilling injury of fruits and vegetables. Food Rev. Int. 1989, 5, 209-236. [CrossRef]

4. Gutiérrez-Pacheco, M.M.; Ortega-Ramírez, L.A.; Silva-Espinoza, B.A.; Cruz-Valenzuela, M.R.; González-Aguilar, G.A.; LizardiMendoza, J.; Miranda, R.; Ayala-Zavala, J.F. Individual and combined coatings of chitosan and carnauba wax with oregano essential oil to avoid water loss and microbial decay of fresh cucumber. Coatings 2020, 10, 614. [CrossRef]

5. El ghaouth, A.; Arul, J.; Ponnampalam, R.; Boulet, M. Use of chitosan coating to reduce water loss and maintain quality of cucumber and bell pepper fruits. J. Food Process. Preserv. 1991, 15, 359-368. [CrossRef]

6. Sami, R.; Elhakem, A.; Alharbi, M.; Benajiba, N.; Almatrafi, M.; Jing, J.; Helal, M. Effect of titanium dioxide nanocomposite material and antimicrobial agents on mushrooms shelf-life preservation. Processes 2020, 8, 1632. [CrossRef]

7. Eldib, R. Application of Nano-coating and Chitosan Combination Films on Cantaloupe Preservation. Pak. J. Biol. Sci. 2020, 23, 1037-1043. [CrossRef] [PubMed]

8. Eldib, R.; Khojah, E.; Elhakem, A.; Benajiba, N.; Helal, M. Chitosan, nisin, silicon dioxide nanoparticles coating films effects on blueberry (vaccinium myrtillus) quality. Coatings 2020, 10, 962. [CrossRef]

9. Rokayya, S.; Jia, F.; Li, Y.; Nie, X.; Xu, J.; Han, R.; Yu, H.; Amanullah, S.; Almatrafi, M.M.; Helal, M. Application of nano-titanum dioxide coating on fresh Highbush blueberries shelf life stored under ambient temperature. LWT 2021, 137, 110422. [CrossRef]

10. Li, Y.; Rokayya, S.; Jia, F.; Nie, X.; Xu, J.; Elhakem, A.; Almatrafi, M.; Benajiba, N.; Helal, M. Shelf-life, quality, safety evaluations of blueberry fruits coated with chitosan nano-material films. Sci. Rep. 2021, 11, 55. [CrossRef]

11. Sami, R.; Elhakem, A.; Alharbi, M.; Benajiba, N.; Almatrafi, M.; Abdelazez, A.; Helal, M. Evaluation of antioxidant activities, oxidation enzymes, and quality of nano-coated button mushrooms (Agaricus bisporus) during storage. Coatings 2021, 11, 149. [CrossRef]

12. Zhou, Y.; Teng, F.; Tian, T.; Sami, R.; Wu, C.; Zhu, Y.; Zheng, L.; Jiang, L.; Wang, Z.; Li, Y. The impact of soy protein isolate-dextran conjugation on capsicum oleoresin (Capsicum annuum L.) nanoemulsions. Food Hydrocoll. 2020, 108, 105818. [CrossRef]

13. Moll, J.; Okupnik, A.; Gogos, A.; Knauer, K.; Bucheli, T.D.; van der Heijden, M.G.A.; Widmer, F. Effects of titanium dioxide nanoparticles on red clover and its rhizobial symbiont. PLoS ONE 2016, 11, e0155111. [CrossRef] [PubMed]

14. Rokayya, S.; Khojah, E.; Elhakem, A.; Benajiba, N.; Chavali, M.; Vivek, K.; Iqbal, A.; Helal, M. Investigating the nano-films effect on physical, mechanical properties, chemical changes, and microbial load contamination of white button mushrooms during storage. Coatings 2021, 11, 44. [CrossRef]

15. Hafez, E.M.; Osman, H.S.; Gowayed, S.M.; Okasha, S.A.; Omara, A.E.; Sami, R.; Abd El-Monem, A.M.; Abd El-Razek, U.A. Minimizing the Adversely Impacts of Water Deficit and Soil Salinity on Maize Growth and Productivity in Response to the Application of Plant Growth-Promoting Rhizobacteria and Silica Nanoparticles. Agronomy-Basel. Agronomy 2021, 11, 676. [CrossRef]

16. Sami, R.; Elhakem, A.; Almushhin, A.; Alharbi, M.; Almatrafi, M.; Benajiba, N.; Fikry, M.; Helal, M. Enhancement in physicochemical parameters and microbial populations of mushrooms as influenced by nano-coating treatments. Sci. Rep. 2021, 11, 7915. [CrossRef]

17. Shah, B.R.; Li, Y.; Jin, W.; An, Y.; He, L.; Li, Z.; Xu, W.; Li, B. Preparation and optimization of Pickering emulsion stabilized by chitosan-tripolyphosphate nanoparticles for curcumin encapsulation. Food Hydrocoll. 2016, 52, 369-377. [CrossRef]

18. Saad, M.M. Effect of some postharvest treatments on reducing chilling injury of cucumber fruits during cold storage. J. Ann. Agric. Sci. Moshtohor. 2019, 57, 455-468. [CrossRef]

19. İbrahim, K.; Serhat, U. Improving postharvest storage quality of cucumber fruit by modified atmosphere packaging and biomaterials. HortScience Horts 2019, 54, 2005-2014. [CrossRef]

20. Sami, R.; Elhakem, A.; Alharbi, M.; Benajiba, N.; Fikry, M.; Helal, M. The combined effect of coating treatments to nisin, nano-silica, and chitosan on oxidation processes of stored button mushrooms at $4{ }^{\circ} \mathrm{C}$. Sci. Rep. 2021, 11, 6031. [CrossRef]

21. Moalemiyan, M.; Ramaswamy, H.S. Quality retention and shelf-life extension in mediterranean cucumbers coated with a pectin-based film. J. Food Res. 2012, 1, 159-168. [CrossRef]

22. Sami, R.; Almatrafi, M.; Elhakem, A.; Alharbi, M.; Benajiba, N.; Helal, M. Effect of nano silicon dioxide coating films on the quality characteristics of fresh-cut cantaloupe. Membranes 2021, 11, 140. [CrossRef] [PubMed]

23. Feng, H.X.; Sam, R.; Jiang, L.Z.; Li, Y.; Cao, W.M. High-performance size-exclusion chromatography studies on the formation and distribution of polar compounds in camellia seed oil during heating. J. Zhejiang Univ. Sci. B 2016, 17, 882-891. [CrossRef] [PubMed]

24. Qiao, G.H.; Wenxin, D.; Zhigang, X.; Sami, R.; Khojah, E.; Amanullah, S. Antioxidant and anti-inflammatory capacities of pepper tissues. Ital. J. Food Sci. 2020, 32, 265-274.

25. Elhakem, A.H.; Almatra, M.M.; Benajiba, N.; Koko, M.Y.; Sami, R. Comparative analysis of bioactive compounds, antioxidant and anti-inflammatory activities of apple varieties. Asian J. Plant Sci. 2020, 20, 61-66. [CrossRef]

26. Qiao, G.; Xiao, Z.; Ding, W.; Rok, A. Effect of chitosan/nano-titanium dioxide/thymol and tween films on ready-to-eat cantaloupe fruit quality. Coatings 2019, 9, 828. [CrossRef] 
27. Olawuyi, I.F.; Park, J.J.; Lee, J.J.; Lee, W.Y. Combined effect of chitosan coating and modified atmosphere packaging on fresh-cut cucumber. Food Sci. Nutr. 2019, 7, 1043-1052. [CrossRef] [PubMed]

28. Sami, R.; Khojah, E.; Elhakem, A.; Benajiba, N.; Helal, M.; Alhuthal, N.; Alzahrani, S.A.; Alharbi, M.; Chavali, M. Performance study of nano $/ \mathrm{SiO}_{2}$ films and the antimicrobial application on cantaloupe fruit shelf-life. Appl. Sci. 2021, 11, 3879. [CrossRef]

29. Sami, R.; Soltane, S.; Helal, M. Microscopic image segmentation and morphological characterization of novel chitosan/silica nanoparticle/nisin films using antimicrobial technique for blueberry preservation. Membranes 2021, 11, 303. [CrossRef]

30. Mohamed, M.A.A.; El-Khalek, A.F.A.; Elmehrat, H.G.; Mohamed, G.A. Pre-storage application of antioxidant alleviates chilling injury and maintains quality of Valencia orange fruit stored at low temperature. Egypt. J. Hortic. 2016, 43, 175-193. [CrossRef]

31. Ghidelli, C.; Mateos, M.; Rojas-Argudo, C.; Pérez-Gago, M.B. Extending the shelf life of fresh-cut eggplant with a soy proteincysteine based edible coating and modified atmosphere packaging. Postharvest Biol. Technol. 2014, 95, 81-87. [CrossRef]

32. Rokayya, S.; Garsa, A.; Eman, E.; Helal, M. Saudi community care awareness food facts, nutrients, immune system and covid-19 prevention in taif city among different age categories. Afr. J. Food Agric. Nutr. Dev. 2021, 21, 17213-17233. [CrossRef]

33. Sami, R.A.; Khojah, E.Y.; Elgarni, E.A.; Benajiba, N. Evaluation of nutritional status for some sensitive sets and its relationship to natural antioxidants. J. King Abdulaziz Univ. Med Sci. 2017, 24, 1-9. [CrossRef]

34. El-din, H.; Anean, H.A.; Aly, H.H. Effect of some edible coatings on storability of organic cucumber fruit. Egypt. J. Agric. Res. 2015, 93, 1013-1029.

35. Sami, R.; Li, Y.; Qi, B.; Wang, S.; Zhang, Q.; Han, F.; Ma, Y.; Jing, J.; Jiang, L. HPLC analysis of water-soluble vitamins (B2, B3, B6, B12, and C) and fat-soluble vitamins (E, K, D, A, and $\beta$-Carotene) of okra (Abelmoschus esculentus). J. Chem. 2014, $2014,831357$. [CrossRef]

36. Sami, R.; Elhakem, A.; Alharbi, M.; Benajiba, N.; Almatrafi, M.; Helal, M. Nutritional values of onion bulbs with some essential structural parameters for packaging process. Appl. Sci. 2021, 11, 2317. [CrossRef]

37. Rokayya, S.; Li, C.J.; Zhao, Y.; Li, Y.; Sun, C.H. Cabbage (Brassica oleracea L. var. capitata) phytochemicals with antioxidant and anti-inflammatory potential. Asian Pac. J. Cancer Prev. 2013, 14, 6657-6662. [CrossRef]

38. Vallverdú-Queralt, A.; Arranz, S.; Medina-Remón, A.; Casals-Ribes, I.; Lamuela-Raventós, R.M. Changes in phenolic content of tomato products during storage. J. Agric. Food Chem. 2011, 59, 9358-9365. [CrossRef] [PubMed]

39. Camargo, J.M.; Dunoyer, A.T.; García-Zapateiro, L.A. The effect of storage temperature and time on total phenolics and enzymatic activity of sapodilla (Achras sapota L.). Rev. Fac. Nac. Agron. Medellín 2016, 69, 7955-7963. [CrossRef]

40. Sami, R. Antioxidant properties of peptides from soybean meal protein hydrolysates evaluated by electron spin resonance spectrometry. Adv. Environ. Biol. 2017, 11, 12-18.

41. Elhake, A.H.; Benajiba, N.; Koko, M.Y.; Khojah, E.; Rok, A. DPPH, FRAP and TAEC assays with postharvest cabbage (Brassica oleracea) parameters during the packaging process. Pak. J. Biol. Sci. 2021, 24, 182-187. [CrossRef]

42. Wang, H.; Sun, Y.; Li, Y.; Tong, X.; Regenstein, J.M.; Huang, Y.; Ma, W.; Sami, R.; Qi, B.; Jiang, L. Effect of the condition of spray-drying on the properties of the polypeptide-rich powders from enzyme-assisted aqueous extraction processing. Dry. Technol. 2019, 37, 2105-2115. [CrossRef]

43. Khojah, E.Y.; Sami, R. Fatty acids composition and oxidative stability of peanut and sesame oils with the sensory evaluation of mayonnaise prepared by different oils. Assiut J. Agric. Sci. 2016, 47, 460-472.

44. Walkowiak-Tomczak, D.; Idaszewska, N.; Bieńczak, K.; Kómoch, W. The effect of mechanical actions occurring during transport on physicochemical changes in Agaricus bisporus mushrooms. Sustainability 2020, 12, 4993. [CrossRef]

45. Zhang, Y.; Zhang, M.; Yang, H. Postharvest chitosan-g-salicylic acid application alleviates chilling injury and preserves cucumber fruit quality during cold storage. Food Chem. 2015, 174, 558-563. [CrossRef] [PubMed]

46. Zhao, Y.; Mingfeng, C.; Aiqiang, C.; Na, Z.; Songsong, Z. Analysis about heat transfer of vegetables during cold shock treatment and preservation quality after storage. J. Int. J. Food Eng. 2017, 13. [CrossRef]

47. Koh, P.C.; Noranizan, M.A.; Karim, R.; Nur Hanani, Z.A.; Rosli, S.Z.; Hambali, N.H. Enzymatic activity of alginate coated and pulsed light treated fresh-cut cantaloupes (Cucumis melo L. var. reticulatus cv. Glamour) during chilled storage. Int. Food Res. J. 2019, 26, 547-556.

48. Waewthongrak, W.; Pisuchpen, S.; Leelasuphakul, W. Effect of bacillus subtilis and chitosan applications on green mold (Penicilium digitatum Sacc.) decay in citrus fruit. Postharvest Biol. Technol. 2015, 99, 44-49. [CrossRef] 